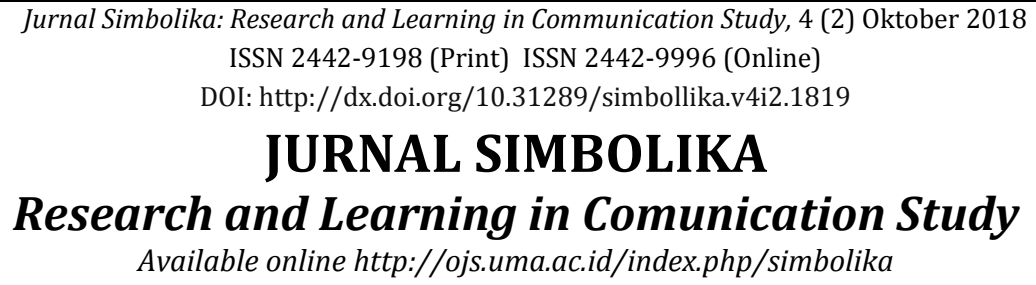

\title{
Pengaruh Gaya Kepemimpinan Perempuan Terhadap Iklim Komunikasi Dan Kinerja Pegawai Pada Dinas Sosial
}

\section{The Effect Of Women's Leadership Style On Communications Climate And Employees Performance On Department of Social Service}

\author{
Hariyono \\ Magister Ilmu Komunikasi, Fakultas Ilmu Sosial dan Ilmu Politik, \\ Universitas Sumatera Utara, Indonesia. \\ *Coresponding Email: hariyono954@gmail.com
}

Abstrak

Tujuan dari penelitian ini adalah untuk menganalisis Pengaruh Gaya Kepemimpinan Perempuan terhadap iklim komunikasi dan kinerja pegawai pada Dinas Sosial Kabupaten Aceh Tamiang. Teori yang digunakan adalah teori gaya kepemimpinan oleh Kartini Kartono, teori iklim komunikasi oleh Face dan Faules dan teori birokrasi organisasi oleh Max Weber. Metode Penelitian ini merupakan metodologi kuantitatif, menggunakan metode Survey ekplanatif dengan analisis statistik regresi linear sederhana. Hasil hipotesis kemudian di uji dengan uji t. Analisis data menggunakan software pengolahan data statistik SPSS 24.0 for windows. Populasi dalam penelitian ini berjumlah 58 orang, maka jumlah sampelnya diambil secara keseluruhan, sehingga penelitian ini merupakan penelitian populasi. Dari hasil uji hipotesis yang dilakukan secara parsial menunjukkan bahwa terdapat pengaruh yang positif dan signifikan antara gaya kepemimpinan perempuan terhadap iklim komunikasi dan kinerja pegawai pada Dinas Sosial Kabupaten Aceh Tamiang. Gaya kepemimpinan perempuan yang mampu mengarahkan, membimbing dan mengatur bawahan dengan baik serta mampu membangun suasana kekeluargaan dalam organisasi ternyata mampu menciptakan dan memberikan iklim komunikasi yang positif serta dapat meningkatkan kinerja pegawai yang baik pula.

Kata kunci: Gaya Kepemimpinan Perempuan, Iklim Komunikasi dan Kinerja Pegawai.

Abstract

The purpose of this study was to analyze the effect of women's leadership style on communications climate and employees performance on Departement of Social Service on Aceh Tamiang Regency. Leadership Style Theory by Kartini Kartono, Communications Climate Theory by Pace and Faules, Bureaucracy Theory by Weber. Quantitative approaches and explanatory surveys with simple regression analyzes were employed as methods of this study, and t-test used to test the hypothesis. Data were analyzed with SPSS 24. Sampling using saturated sampling method, all members of population used as sample. The number of samples are 58 people. The results of this study show that women's leadership style has positive and significant effect on the communications climate and employee performance on Department of Social Service on Aceh Tamiang Regency. Women's leadership styles that able to direct, guide and organize and also able to build a family atmosphere in the organization, will be able to create and provide a positive communications climate and can improve employee performance as well.

Keywords: Women's Leadership Style, Communications Climate and Employee Performance.

How to Cite: Hariyono. (2018). Pengaruh Gaya Kepemimpinan Perempuan terhadap Iklim Komunikasi dan Kinerja Pegawai pada Dinas Sosial Kabupaten Aceh Tamiang. Jurnal Simbolika: Research and Learning in Communication Study. 4 (2): 73-85. 


\section{PENDAHULUAN}

Kepemimpinan adalah kekuatan inspirasional, kekuatan semangat, dan kekuatan moral yang kreatif, yang bisa mempengaruhi seluruh anggota yang berada dalam suatu organisasi untuk merubah sikap sehingga mereka menjadi konform dengan keinginan pemimpinnya.

Kepemimpinan seorang Perempuan menjadi sebuah isu publik yang hangat diperbincangkan, dan telah memancing polemik dan debat antara yang pro dan kontra terhadap pemimpin perempuan dalam sebuah organisasi, kendatipun pengakuan atas hak dasar kemanusiaan tampak mengalami peningkatan yang signifikan diberbagai belahan dunia. Pengakuan ini juga berlaku atas hak Perempuan sebagaimana yang sejajar dengan laki-laki. Stigma bahwa Perempuan tidak perlu sekolah setinggi-tingginya, toh akhirnya ke dapur juga seringkali dijadikan sebagai alat untuk membenarkan tindakan tidak adil terhadap kaum Perempuan.

Sehubungan dengan isu gender dan kepemimpinan Robbins mengemukakan dua kesimpulan, yaitu: Pertama, mengabaikan perbedaan antara laki-laki dan Perempuan cenderung menyamakan diantara keduanya. Kedua, bahwa apa yang menjadi perbedaan antara Perempuan dan laki-laki adalah bahwa
Perempuan memiliki gaya kepemimpinan yang lebih democratic, sedangkan laki-laki lebih kepada gaya kepemimpinan yang bersifat directive (menekankan pada caracara yang bersifat perintah).

Dalam pencapaian tujuan organisasi pemimpin mejalankan peranan kepemimpinan dan komunikasi dengan baik dan efektif, sehingga pemimpin diharapkan dapat menggerakkan pegawai melalui pendekatan dan pembinaan yang terarah sesuai dengan keinginan dan kemampuan pegawai. Seorang pemimpin harus mampu menciptakan situasi dan kondisi serta iklim komunikasi organisasi yang dapat memacu semangat kerja pegawai baik ketika bekerja secara perseorangan maupun bekerja secara kelompok atau teamwork.

Iklim komunikasi organisasi merupakan fungsi kegiatan yang terdapat dalam organisasi untuk menunjukkan kepada anggota organisasi bahwa organisasi tersebut mempercayai mereka dan memberikan mereka kebebasan untuk mengambil resiko; mendorong mereka dan memberi mereka tanggung jawab dalam mengerjakan tugastugas mereka; menyediakan informasi yang terbuka dan cukup tentang organisasi; mendengarkan dengan penuh perhatian serta memperoleh infomasi yang dapat dipercayai dan terus terang dari anggota organisasi; secara aktif memberi penyuluhan kepada para 
anggota organisasi sehingga mereka melihat bahwa keterlibatan mereka penting bagi keputusan dalam organisasi (Pace dan Faules, 2010).

Iklim komunikasi organisasi yang efektif merupakan sesuatu hal yang harus dijadikan pertimbangan oleh seorang pemimpin organisasi, hal ini dikarenakan suatu iklim komunikasi organisasi memiliki pengaruh yang sangat besar terhadap tingkat kinerja pegawai pada suatu organisasi (Muhammad, 2005). Hal ini dapat diketahui bahwa keberhasilan suatu organisasi didalam membangun suatu komunikasi organisasi yang baik dan efektif bagi para pegawai sangatlah penting dalam meningkatkan kinerja pegawai.

Kinerja menurut Suntoro (dalam Tika, 2006) kinerja adalah hasil kerja yang dapat dicapai seseorang atau sekelompok orang dalam suatu organisasi dalam rangka mencapai tujuan organisasi dalam periode waktu tertentu.

Dalam suatu organisasi kinerja perorangan (individual perfomance) sangat menentukan kinerja organisasi (organization perfomance), organisasi dalam mencapai visi dan misi yang telah ditetapkan tentunya melalui kegiatankegiatan yang digerakkan oleh orang atau sekelompok orang yang bekerja sama dan aktif berperan sebagai pelaku dalam menghasilkan kinerja organisasi yang baik.

Dinas Sosial Kabupaten Aceh Tamiang memiliki peran strategis dalam menyusun dan melaksanakan kebijakan daerah dibidang akses pelayanan sosial bagi masyarakat. Dalam melaksanakan perannya tersebut pegawai yang memiliki kemampuan dan keahlian dibidangnya menjadi faktor utama dalam melaksanakan tugas dan fungsi pada Dinas Sosial Kabupaten Aceh Tamiang tersebut.

Berdasarkan pengamatan peneliti pada instansi tersebut, dapat diketahui bahwa pada Tahun 2016 kepemimpinan Dinas Sosial Kabupaten Aceh Tamiang tersebut dipimpin oleh seorang laki-laki, dalam kepemimpinan tersebut kinerja pegawai pada instansi pemerintah tersebut dapat dikatakan kurang begitu baik. Hal ini dapat dilihat dari hasil Laporan Akuntabilitas Kinerja Instansi Pemerintah (LAKIP) pada Dinas Sosial Kabupaten Aceh Tamiang Tahun Anggaran 2016, dengan realisasi anggaran dari dana APBK adalah sebesar 74,84\% dengan capaian kinerja sebasar 78,95\%. Selain itu kinerja pegawai Dinas Sosial Kabupaten Aceh Tamiang dalam penyelenggaraan administrasi kurang begitu baik karena sering terjadinya kehilangan surat penting instansi yang dibutuhkan sebagai arsip dinas yang disebabkan rendahnya tingkat 
pengarsipan surat penting dinas. Aceh Tamiang menuju keadaan yang lebih Selanjutnya seringnya pimpinan memaksakan kehendak kepada bawahan dalam melaksanakan tugasnya sesuai dengan kehendak dan persepsinya sendiri sehingga tidak dapat menerima pendapat dan saran dari bawahannya hal ini memperlihatkan bahwa kurangnya komunikasi antara pimpinan dan bawahan. Rendahnya tingkat pertemuan pelaksanaan rapat koordinasi, monitoring dan evaluasi antara pimpinan dan bawahan sehingga seringnya terjadi kesalahan pahaman dalam pelaksanaan tugas dan fungsi masing-masing pegawai dalam mencapai tujuan organisasi. Kinerja yang belum maksimal seperti yang disebutkan diatas berbanding terbalik ketika pada tahun 2017 Dinas Sosial Kabupaten Aceh Tamiang tersebut dipimpin oleh seorang perempuan. Sesuai dengan hasil Laporan Akuntabilitas Kinerja Instansi Pemerintah (LAKIP) pada Dinas Sosial Kabupaten Aceh Tamiang Tahun Anggaran 2017 dengan realisasi anggaran dari dana APBK adalah sebesar $80,42 \%$ dan capaian kinerja sebesar 85.01\% dengan kategori capaian sangat baik. Meskipun Dinas Sosial Kabupaten Aceh Tamiang dipimpin oleh seorang kepala Dinas perempuan, tidak menutup kemungkinan akan adanya energi positif yang membawa Dinas Sosial Kabupaten aju. Sesuai dengan gaya kepemimpinan yang dimiliki, masing-masing pihak dalam hal ini pegawai diminta dan dituntut untuk aktif dalam menjalankan tugas dan tanggungjawabnya.

Namun, hal yang menarik dalam Dinas Sosial Kabupaten Aceh Tamiang tersebut adalah ketika suatu instansi pemerintah daerah dipimpin oleh seorang perempuan. Terlepas dari banyaknya perempuan yang menjadi pemimpin dan memegang peranan penting pada saat ini, yang menarik adalah mengamati gaya kepemimpinan mereka.

Berdasarkan latarbelakang dan rumusan masalah yang telah diuraikan diatas, maka tujuan penelitian ini adalah untuk: 1) menganalisis pengaruh gaya kepemimpinan perempuan terhadap iklim komunikasi pada Dinas Sosial Kabupaten Aceh Tamiang, 2) menganalisis pengaruh gaya kepemimpinan perempuan terhadap kinerja pegawai pada Dinas Sosial Kabupaten Aceh Tamiang.

Berdasarkan latar belakang dan rumusan masalah dapat dirumuskan hipotesis sebagai berikut:

H1: Terdapat pengaruh antara Gaya Kepemimpinan Perempuan (X) terhadap Iklim Komunikasi $\left(\mathrm{Y}_{1}\right)$ pada Dinas Sosial Kabupaten Aceh Tamiang. 
H2: Terdapat pengaruh antara Gaya Kepemimpinan Perempuan

$(\mathrm{X})$ terhadap Kinerja Pegawai $\left(\mathrm{Y}_{2}\right)$ pada Dinas Sosial Kabupaten Aceh Tamiang.

\section{METODE PENELITIAN}

Penelitian ini merupakan penelitian metodologi kuantitatif, menggunakan metode Survey ekplanatif dengan sifat asosiatif dengan maksud menjelaskan hubungan (korelasi) antar variabel. Penelitian ini tidak hanya sekedar menggambarkan terjadinya fenomena tetapi telah mencoba menjelaskan mengapa fenomena itu terjadi dan apa pengaruhnya. (Kriyantono, 2010)

Adapun lokasi penelitian berada di Kompleks Perkantoran Bupati Aceh Tamiang tepatnya pada Dinas Sosial Kabupaten Aceh Tamiang.

Menurut Singarimbun dan Efendi (2008), definisi konseptual adalah pemaknaan dari konsep yang digunakan, sehingga memudahkan peneliti untuk mengoperasikan konsep tersebut di lapangan. Definisi konsep digunakan untuk memperjelas pengertian variabel-variabel yang akan diteliti. Operasional variabel dalam penelitian ini adalah sebagai berikut:

Variabel Bebas (X) dalam penelitian ini adalah Gaya Kepemimpinan Perempuan

pada Dinas Sosial Kabupaten Aceh Tamiang.

Variabel Terikat $\left(\mathrm{Y}_{1}\right)$ dalam penelitian ini adalah Iklim Komunikasi pada Dinas Sosial Kabupaten Aceh Tamiang.

Variabel Terikat $\left(\mathrm{Y}_{2}\right)$ dalam penelitian ini adalah Kinerja Pegawai pada Dinas Sosial Kabupaten Aceh Tamiang.

Karakteristik Responden pada penelitian ini adalah umur, jenis kelamin, pendidikan terakhir, golongan pekerjaan, lama bekerja, tingkat penghasilan.

Tabel 1. Variabel Operasional

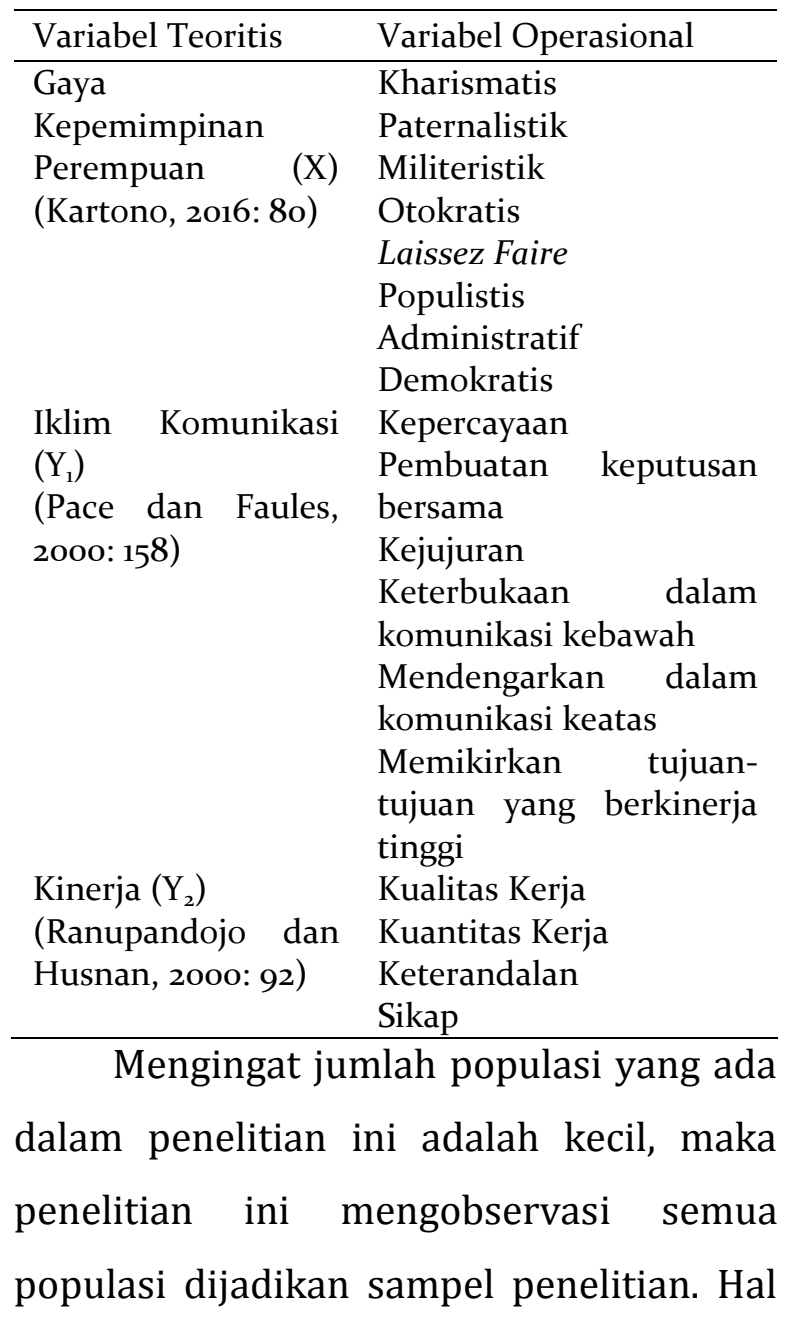


ini dipertegas dengan pendapat Arikunto (2006) yang menyatakan bahwa apabila populasi kurang dari 100, maka jumlah sampelnya diambil secara keseluruhan, sehingga penelitian ini merupakan penelitian populasi. Dalam penelitian ini jumlah populasi sebanyak 58 orang, maka jumlah sampelnya diambil secara keseluruhan karena dalam penelitian ini jumlah populasi sama dengan jumlah sampel.

Skala pengukuran variabel yang digunakan dalam penelitian ini merupakan skala Likert. Menurut Sugiyono (2012) Skala Likert digunakan untuk mengukur sikap, pendapat, dan persepsi seseorang atau sekelompok orang tentang fenomena sosial.

Data primer diperoleh dari jawaban responden terhadap kuesioner yang disebarkan kepada sampel yaitu pegawai, kuesioner ini dimaksudkan untuk mendapatkan data yang dibutuhkan untuk memperoleh informasi dari responden mengenai gaya kepemimpinan perempuan terhadap iklim komunikasi dan kinerja pegawai pada Dinas Sosial Kabupaten Aceh Tamiang.

Data sekunder adalah data yang diperoleh dalam bentuk yang sudah diolah berupa dokumen organisasi dan publikasi yang dikumpulkan oleh pihak atau instansi lain. Data sekunder dalam penelitian ini meliputi profil Dinas Sosial Kabupaten Aceh Tamiang, struktur organisasi dan data yang diperoleh dari hasil pengolahan buku, teori-teori dan literature yang berhubungan dengan masalah yang diteliti. Analisis data dilakukan dengan bantuan aplikasi komputer SPSS Versi 24. Telah dilakukan juga uji validitas dan reliabilitas instrumen penelitian.

Uji hipotesis dilakukan dengan secara parsial menggunakan analisis regresi linear sederhana untuk melihat pengaruh antara variabel independen dengan variabel dependen. Dalam penelitian ini untuk menunjukkan seberapa jauh pengaruh variabel independen secara parsial terhadap variabel dependen ditentukan dengan ujit.

HASIL DAN PEMBAHASAN

1. Penjelasan Responden terhadap Variabel Gaya Kepemimpinan
Perempuan

Tabel 2.

Rata-rata masing gaya kepemimpinan

\begin{tabular}{ll}
\hline Gaya Kepemimpinan & Mean \\
\hline Kahrismatik & 3,38 \\
Paternalistik & 3,38 \\
Militeristik & 3,48 \\
Otokratis & 3,29 \\
Laissez Faire & 3,38 \\
Populistis & 3,38 \\
Administratif & 3,34 \\
Demokratis & 3,64 \\
\hline
\end{tabular}

Sumber: Hasil penelitian Tahun 2018 
Berdasarkan pada tabel 2. rata-rata masing-masing gaya kepemimpinan hasil perhitungan diperoleh bahwa gaya kepemimpinan demokratis yang memiliki rata-rata tertinggi. Hal ini menunjukkan bahwa dalam menjalankan tugas pokok dan fungsinya sebagai kepala dinas lebih dominan menerapkan gaya kepemimpinan demokratis yang mampu untuk mempengaruhi dan memotivasi orang lain serta membuat orang lain mampu memberikan kontribusinya demi efektifitas dalam mencapai tujuan organisasi. Hal ini ternyata sejalan dengan pendapat Robbins (1998) bahwa perempuan cenderung memiliki gaya kepemimpinan yang lebih democratic.

\section{Pengaruh Gaya Kepemimpinan}

Perempuan terhadap Iklim

Komunikasi pada Dinas Sosial

\section{Kabupaten Aceh Tamiang}

Dari hasil analisis regresi linear sederhana diketahui bahwa Gaya kepemimpinan perempuan pada Dinas Sosial Kabupaten Aceh Tamiang memberikan pengaruh yang positif dan signifikan terhadap iklim komunikasi hal ini berdasarkan hasil pengolahan data statistik dapat diketahui nilai koefisien regresi sebesar 0,183. Ini memberi arti bahwa setiap penambahan 1\% tingkat gaya kepemimpinan perempuan, maka iklim komunikasi $\left(\mathrm{Y}_{1}\right)$ akan meningkat sebesar 0,183. Karena nilai koefisien regresi bernilai $(+)$, maka dengan demikian dapat dikatakan bahwa Gaya Kepemimpinan Perempuan

berpengaruh positif terhadap Iklim Komunikasi $\left(\mathrm{Y}_{1}\right)$ pada Dinas Sosial Kabupaten Aceh Tamiang. Akan tetapi untuk mengetahui diterima atau ditolaknya hipotesis digunakan uji-t, dengan demikian bahwa gaya kepemimpinan perempuan Dinas Sosial Kabupaten Aceh Tamiang memberikan pengaruh positif dan signifikan terhadap iklim komunikasi hal ini dapat diketahui bahwa nilai thitung $(3,181)$ lebih besar dibandingkan dengan nilai $t_{\text {tabel }}(1,673)$, dan nilai Sig $t$ untuk variabel gaya kepemimpinan perempuan (0.002) lebih kecil dari $\alpha(0,05)$.

Berdasarkan hasil penelitian ditemukan bahwa gaya kepemimpinan perempuan memiliki pengaruh yang positif dan signifikan terhadap iklim komunikasi. Gaya kepemimpinan perempuan yang diterapkan oleh Kepala Dinas Sosial Kabupaten Aceh Tamiang dapat meningkatkan iklim komunikasi diantaranya pegawai merasakan dukungan dalam organisasi terhadap kinerjanya, tidak adanya tekanan yang dirasakan oleh pegawai dalam menjalankan tugas dan fungsinya, pegawai selalu dilibatkan dalam setiap pengambilan keputusan dalam 
organisasi terkait dengan hal pekerjaan, pegawai diberikan kepercayaan penuh dari atasan dalam hal pekerjaan, pegawai selalu mudah memperoleh akses informasi yang berkaitan dengan pekerjaan serta adanya sifat keterbukaan antara atasan dan bawahan dan sesama rekan kerja dalam organisasi pada Dinas Sosial Kabupaten Aceh Tamiang.

Dari hasil penelitian ini dapat diketahui bahwa iklim komunikasi yang dibentuk oleh Kepala Dinas Sosial Kabupaten Aceh Tamiang dalam menjalankan roda organisasi bersifat positif, sehingga semakin diterapkannya gaya kepemimpinan maka semakin tinggi pula iklim komunikasi yang dirasakan. Dalam hal ini iklim komunikasi yang ada pada Dinas Sosial Kabupaten Aceh Tamiang sudah berada pada tingkat yang cukup baik. Proses komunikasi dan kerjasama pasti selalu terjadi baik komunikasi antara atasan dan bawahan maupun antara individu dan kelompok, inilah yang tentunya memberikan pengaruh yang besar terhadap pembentukan iklim komunikasi pada Dinas Sosial Kabupaten Aceh Tamiang. Jika pemimpin melakukan suatu proses komunikasi juga akan dipikirkan dampak maupun efek yang akan terjadi nantinya. Iklim komunikasi merupakan gabungan dari persepsi-persepsi suatu evaluasi

makro mengenai peristiwa komunikasi, perilaku manusia, respon terhadap pegawai lainnya, harapan-harapan, konflik antarpersonal dan kesempatan bagi pertumbuhan dalam organisasi tersebut untuk dapat memberikan kepuasan bagi pegawai di Dinas Sosial Kabupaten Aceh Tamiang.

Kepala Dinas Sosial Kabupaten Aceh Tamiang sebagai sosok seorang pemimpin perempuan yang mampu menjalin dan membangun hubungan yang baik dengan para pegawainya dan mampu menciptakan suasana kekeluargaan dalam organisasi. Selain itu kepala Dinas Sosial Kabupaten Aceh Tamiang selalu menunjukkan kepedulian dan perhatiannya terhadap bawahannya, sehingga bawahannya menjadi semangat dalam menjalankan tugas dan tanggungjawabnya dalam menyelesaikan setiap pekerjaan dalam organisasi. Hal ini sejalan dengan pendapat Tannen (1995) yang menyatakan bahwa pemimpin yang menekankan pada hubungan dan keakraban yang cenderung dimiliki oleh perempuan, memungkinkan seorang pemimpin tersebut bersikap bahwa pada hakikatnya semua orang itu berhak mendapat perlakuan yang sama, memberdayakan segenap anggotanya serta menekankan pada struktur organisasi. 
Berdasarkan hasil penelitian ditemukan juga bahwa kepala Dinas Sosial Kabupaten Aceh Tamiang memegang peranan yang sangat penting dalam melakukan monitoring dan evaluasi perilaku pegawai untuk meningkatkan kinerja pegawai. Monitoring dan evaluasi dilakukan secara berkala dan konsisten dimana setiap kegiatan bidang dan organisasi pemimpin memberikan pengarahan kepada setiap bawahannya dan hasil kerja selalu di evaluasi. Hal ini sejalan dengan salah satu fungsi pemimpin adalah sebagai kontroler (pengendali), dimana pemimpin melaksanakan fungsi pengawasan terhadap berbagai aktifitas organisasi agar terhindar dari penyimpangan dalam pelaksanaan rencana dan atau program kerja organisasi Dinas Sosial Kabupaten Aceh Tamiang sehingga tujuan organisasi menjadi efektif dan efisien.

Fungsi pemimpin sebagai motivator dimana Kepala Dinas Sosial Kabupaten Aceh Tamiang merencanakan dan membuat kebijakan, mengelola dan menganalisis kebutuhan organisasi yang mengarah kepada upaya mendorong pegawai untuk melaksanakan suatu kegiatan tertentu sesuai dengan tugas dan fungsinya sehingga mampu memberikan kontribusi terhadap keberhasilan pencapaian tujuan organisasi. Hal ini dibuktikan dengan selalu adanya arahan dan dukungan yang diberikan kepada pegawai untuk melaksanakan pekerjaan sehari-hari dalam meningkatkan kinerja pegawai.

Kemampuan kepala Dinas Sosial Kabupaten Aceh Tamiang untuk mengatur bawahan dengan baik dan memiliki kemampuan manajerial birokrasi yang baik tidak terlepas dari berjalannya fungsi pemimpin sebagai inovator dan komunikator yang unggul, sehingga dapat meningkatkan kinerja pegawai dan kinerja organisasi.

Fungsi kepemimpinan pada Dinas Sosial Kabupaten Aceh Tamiang berjalan dengan baik selaras dengan fungsi kepemimpinan menurut Gorda (2004) yaitu sebagai inovator, komunikator, motivator dan kontroler (pengendali). Ini sejalan dengan pendapat Hasibuan (2005) kepemimpinan adalah cara seorang pemimpin dalam mempengaruhi perilaku bawahan agar mau bekerja sama dan bekerja secara produktif untuk mencapai tujuan organisasi. Oleh sebab itu pemimpin harus mampu memandu, mengatur, membimbing, memberikan membangun motivasi kerja serta menjalin komunikasi yang baik dalam memberikan pengawasan yang efektif dan efesien dalam rangka peningkatan kinerja. 
Hal yang masih harus ditingkatkan oleh kepala Dinas Sosial Kabupaten Aceh Tamiang adalah keberanian dalam mengambil keputusan dalam setiap kebijakan yang diambil untuk mencapai tujuan organisasi dengan memeperhitungkan keuntungan dan resiko dari setiap keputusan yang akan diambil. Keberanian dalam mengambil keputusan diperlukan agar para pegawai atau bawahan memperoleh kepastian dalam bertindak terutama dalam hal penyelesaian suatu pekerjaan atau kegiatan masing-masing bidang dalam organisasi. Dalam penyelesaian suatu pekerjaan atau kegiatan bidang maupun permasalahan dalam organisasi memerlukan penanganan yang berbedabeda. Untuk itu diperlukan kejelasan aturan, kebijakan dan batasan kewenangan masing-masing pegawai dalam hal pekerjaan, walaupun selama ini kepala Dinas Sosial Kabupaten Aceh Tamiang selalu memberikan tugas dan wewenang kepada bawahan secara objektif sesuai dengan tugas pokok dan fungsinya. Hal ini sejalan dengan teori birokrasi yang dikemukakan oleh Weber (dalam Morissan 2013) bahwa dalam mewujudkan birokrasi rasional dalam menjalankan organisasi harus meliputi 3 (tiga) aspek penting yaitu otoritas, spesialisasi dan peraturan.
3. Pengaruh Gaya Kepemimpinan Perempuan terhadap Kinerja Pegawai pada Dinas Sosial Kabupaten Aceh Tamiang

Berdasarkan hasil pengolahan data diketahui bahwa gaya kepemimpinan perempuan berpengaruh positif dan signifikan terhadap kinerja pegawai pada Dinas Sosial Kabupaten Aceh Tamiang dimana nilai $t_{\text {hitung }}$ sebesar $(4,961)$ lebih besar dari nilai $t_{\text {tabel }}$ sebesar $(1,673)$ dan nilai Sig $t$ untuk variabel gaya kepemimpinan perempuan (0.000) lebih kecil dari $\alpha(0,05)$. Nilai koefisien regresi sebesar 0,229 memberikan arti bahwa setiap penambahan 1\% tingkat gaya kepemimpinan perempuan, maka kinerja pegawai $\left(\mathrm{Y}_{2}\right)$ akan meningkat sebesar 0,229 . Karena nilai koefisien regresi bernilai $(+)$, maka dengan demikian dapat dikatakan bahwa Gaya Kepemimpinan Perempuan (X) berpengaruh positif terhadap kinerja pegawai $\left(\mathrm{Y}_{2}\right)$ pada Dinas Sosial Kabupaten Aceh Tamiang.

Berdasarkan hasil analisa sebelumnya diketahui bahwa gaya kepemimpinan perempuan pada Dinas Sosial Kabupaten Aceh Tamiang memiliki gaya kepemimpinan yang baik. Kepala Dinas Sosial Kabupaten Aceh Tamiang mampu mengatur bawahannya dengan baik, hal ini didukung dengan kemampuan yang multiterampil yang dimiliki 
pemimpin serta kemampuan manajerial birokrasi yang baik. Disamping itu sebagai sosok seorang pemimpin perempuan yang ramah dan berjiwa keibuan, kemampuan kepemimpinannya mampu membina bawahannya menjadi mahir secara teknis, bersemangat/bergairah dalam bekerja, loyal dan bermoral tinggi.

Pemimpin juga aktif memberikan arahan dan dukungan kepada bawahannya dalam hal pekerjaan agar setiap pekerjaan yang dilaksanakan dengan baik dan benar sesuai dengan tujuan organisasi. Dalam memberikan arahan sebenarnya Kepala Dinas Sosial Kabupaten Aceh Tamiang sedang membangun kerangka dan konsep kerja pegawai sekaligus untuk mengembangkan segenap potensi bawahannya dalam melakukan pekerjaan. Setelah arahan dan dukungan dalam pekerjaan yang dilakukan oleh pemimpin tidak terlepas dari adanya monitoring dan evaluasi terhadap segala program/kegiatan bidang dalam organisasi yang dilakukan kepala Dinas Sosial Kabupaten Aceh Tamiang yang dilakukan secara berkala. Monitoring dilakukan untuk mengetahui apakah kegiatan yang sedang berlangsung sesuai dengan perencanaan dan prosedur yang telah disepakati atau tidak serta bagaimana masukan yang dberikan dalam melakukan evaluasi nantinya. Selain itu ada hal yang cukup menarik dalam gaya kepemimpinan perempuan yang ada Dinas Sosial Kabupaten Aceh Tamiang yaitu pemimpin senantiasa selalu menerima setiap ide dan gagasan yang diberikan bawahan ketika membuat suatu keputusan dalam organisasi dan selalu memberikan kebebasan kepada bawahan untuk berpendapat dalam setiap rapat maupun pertemuan lain terkait dalam hal pekerjaan, disini pemimpin menunjukkan sikap yang terbuka dan bekerjasama kepada bawahan sehingga dapat menciptakan solusi yang optimal dan efektif untuk mencapai tujuan organisasi. Hal ini sejalan dengan teori suportif yang dikemukakan Kartono (2016) pemimpin menciptakan suatu lingkungan kerja yang menyenangkan, dan bisa membantu memenuhi keinginan setiap anggotanya untuk melaksanakan pekerjaan sebaik mungkin, sanggup bekerja sama dengan pihak lain, mau mengembangkan bakat dan keterampilannya.

Adanya gaya kepemimpinan perempuan yang kuat pada Dinas Sosial Kabupaten Aceh Tamiang ini menjadikan adanya kinerja pegawai yang tinggi pula. Tingginya kinerja pegawai pada Dinas Sosial Kabupaten Aceh Tamiang dapat ditunjukkan dengan kualitas kerja, kuantitas kerja, keterandalan dan sikap pegawai terhadap pekerjaan dimana 
pegawai berusaha menjalin kerjasama dan komunikasi dengan atasan serta rekan kerja dalam menjalankan tugasnya. Komunikasi yang dibangun oleh pegawai ternyata tidak hanya dilakukan antar pegawai (horizontal) tetapi juga dengan pemimpin (vertikal) dan juga dengan pihak lain yang memiliki kepentingan. Sehingga pegawai dalam melaksanakan tugasnya selalu berorientasi pada kualitas kerja dengan memperhatikan efisiensi, ketepatan waktu, ketelitian, kerapian, kebersihan, keterampilan dan tingkat keberhasilan dalam menyelesaikan suatu pekerjaan. Selain itu kuantitas kerja juga dijadikan sebagai prioritas, ini dapat ditunjukkan dengan seringnya pegawai menyelesaikan pekerjaan pokok maupun pekerjaan tambahan yang diberikan pimpinan sesuai dengan target yang telah ditentukan. Tingkat keterandalan yang dimiliki pegawai Dinas Sosial Kabupaten Aceh Tamiang juga patut untuk diperhitungkan ini terbukti dengan kemampuan pegawai untuk mengikuti instruksi dengan baik, memiliki inisiatif yang tinggi dalam bekerja, mampu berkreatifitas dalam melaksanakan pekerjaan, memiliki tingkat ketekunan, memiliki tingkat kehati-hatian dan memiliki tingkat daya tahan yang tinggi dalam bekerja. Kinerja pegawai yang tinggi didalam hasil penelitian ini juga identik dengan perubahan sikap terhadap pekerjaan. Pegawai pada Dinas Sosial Kabupaten Aceh Tamiang cenderung selalu bekerja dengan penuh semangat, memiliki komitmen yang tinggi, memiliki tanggungjawab terhadap pekerjaan, mampu untuk disiplin, mampu bekerjasama dengan rekan kerja dan memiliki tingkat kepedulian yang tinggi terhadap pekerjaan serta pegawai memiliki motivasi yang tinggi terhadap pekerjaan.

\section{SIMPULAN}

Kepala Dinas Sosial Kabupaten Aceh Tamiang lebih cenderung menerapkan gaya kepemimpinan demokratis. Hasil penelitian secara parsial menunjukkan bahwa gaya kepemimpinan perempuan memiliki pengaruh positif dan signifikan terhadap iklim komunikasi pada Dinas Sosial Kabupaten Aceh Tamiang. Dari hasil penelitian dapat diketahui bahwa iklim komunikasi yang dibentuk oleh Kepala Dinas Sosial Kabupaten Aceh Tamiang dalam menjalankan roda organisasi bersifat positif, sehingga semakin diterapkannya gaya kepemimpinan maka semakin tinggi pula iklim komunikasi yang dirasakan. Hasil penelitian secara parsial diketahui bahwa gaya kepemimpinan perempuan berpengaruh positif dan signifikan terhadap kinerja pegawai pada 
Dinas Sosial Kabupaten Aceh Tamiang. Adanya gaya kepemimpinan perempuan yang kuat pada Dinas Sosial Kabupaten Aceh Tamiang ini menjadikan adanya kinerja yang tinggi pula. Tingginya kinerja pegawai pada Dinas Sosial Kabupaten Aceh Tamiang dapat ditunjukkan dengan kualitas kerja, kuantitas kerja, keterandalan dan sikap pegawai terhadap suatu pekerjaan dimana pegawai berusaha menjalin kerjasama dan komunikasi dengan atasan serta rekan kerja dalam menjalankan tugasnya.

\section{DAFTAR PUSTAKA}

Arikunto, S. (2006). Prosedur Penelitian Suatu Pendekatan Praktik. Jakarta: PT. Rineka Cipta.

Gorda, I.G.N. (2006). Manajemen Sumber Daya Manusia. Denpasar: Astabrata Bali.
Hasibuan, H.M. (2005). Manajemen sumber daya manusia. Jakarta: PT. Bumi Aksara.

Kriyantono, R. (2010). Teknik Praktis Riset Komunikasi: Disertai Contoh Praktis Riset Media, Public Relations, Advertising, Komunikasi Organisasi, Komunikasi Pemasaran. Jakarta: Kencana Prenada Media Group.

Kartono, K. (2016). Pemimpin dan Kepemimpinan. Bandung: PT. Rajawali Grafindo Persada.

Morissan. (2013). Teori Komunikasi: Individu Hingga Massa. Jakarta: Kencana Prenada Media Group.

Pace, R.W. \& Faules. (2010). Komunikasi Organisasi: Strategi Meningkatkan Kinerja Perusahaan. Penerjemah: Deddy Mulyana, M.A., Ph.D. Bandung: PT. Remaja Rosdakarya Offset.

Robbins, S.P. (1998). Organizational Behavior: Concepts, Controversiess, Application, 8th ed, Prentice-Hall International, Inc., New Jersey.

Sugiyono. (2012). Metode Penelitian Kuantitatif, Kualitatif dan R\&D. Bandung: Alfabeta.

Singarimbun, M. \& Effendi, S. (2008). Metode Penelitian Survei. Jakarta: Pustaka LP3ES.

Tika, M.P. (2006). Budaya Organisasi Dan Peningkatan Kinerja Perusahaan. Jakarta: Bumi Aksara.

Tannen, D. (1995). Talking from 9 to 5, William Morrow, New York. 